\title{
Efek Gizi Lebih terhadap Fungsi Paru pada Anak Asma
}

\section{Muhammad Ridho Grahadinta, ${ }^{1}$ Ferry Achmad Firdaus Mansoer, ${ }^{2}$ Lisa Adhia Garina, ${ }^{3}$ Tito Guntara, ${ }^{4}$ Nugraha Sutadipura ${ }^{5}$}

${ }^{1}$ Program Studi Pendidikan Dokter, Fakultas Kedokteran, Universitas Islam Bandung, ${ }^{2}$ Bagian Obstetri dan Ginekologi, Fakultas Kedokteran, RSUD Al-Ihsan, ${ }^{3}$ Bagian Ilmu Kesehatan Anak, Fakultas Kedokteran, Universitas Islam Bandung, ${ }^{5}$ Bagian Biomolekuler, Fakultas Kedokteran, Universitas Islam Bandung

\begin{abstract}
Abstrak
Asma merupakan salah satu penyakit tidak menular kronik dari saluran pernapasan paru yang menyebabkan inflamasi dan penyempitan. Asma sering berhubungan dengan gizi lebih dalam pengembangan maupun memperparah penyakit asma. Perubahan pola pernapasan pada penderita gizi lebih dapat menyebabkan volume paru menurun diakibatkan oleh perubahan pada otot polos dan fungsi pernapasan. Penelitian ini bertujuan menganalisis efek gizi lebih terhadap fungsi paru pada anak dengan asma. Penelitian ini menggunakan studi observasional analitik dengan rancangan penelitian kasus kontrol. Variabel bebas dihubungkan dengan variabel terikat dengan analisis statistik uji chi-square. Data diperoleh dengan melakukan wawancara menggunakan kuesioner ISAAC untuk menentukan diagnosis asma anak. Selanjutnya, dilakukan penilaian fungsi paru langsung menggunakan spirometri serta mengukur tinggi badan menggunakan mikrotoa dan berat badan menggunakan timbangan yang hasilnya dirujuk pada grafik Z score WHO untuk mengukur indeks massa tubuh. Penelitian ini dilakukan di SMPN 1 dan SMPN 9 Kota Bandung periode 1 April-25 Mei 2018. Hasil penelitian ini menunjukkan bahwa anak asma dengan gizi lebih mempunyai risiko restrictive ventilatory defect lebih besar 3,4 kali dibanding dengan anak asma dengan gizi normal (OR:3,4; IK95\%: 1,4-8,5; $\mathrm{p}=0,014)$. Simpulan, anak asma dengan gizi lebih mempunyai efek restrictive ventilatory defect lebih banyak dibanding anak asma dengan gizi normal.
\end{abstract}

Kata kunci: Anak, asma, fungsi paru, gizi lebih

\section{The Effect of Overnutrition on Lung Function in Asthmatic Childhood}

\begin{abstract}
Asthma is a chronic non-communicable disease of the pulmonary respiratory tract which causes inflammation and constriction. Asthma is often associated with overnutrition in developing or exacerbate asthma. Changes in respiratory patterns in patients with overnutrition can cause lung volume caused by smooth muscle disorders and respiratory function. This study aims to analyze the effects of overnutrition on lung function in children with asthma. This study used observational analytic studies with case control research designs. The independent variable varies with the chi-square test statistical analysis. Data were obtained by conducting interviews using the ISAAC questionnaire to determine the diagnosis of childhood asthma. Furthermore, knowing lung function directly using spirometry also measured height by mikrotoa and weight by the scales that are being referred to the WHO Z score to measure body mass index. This research was conducted at SMPN 1 and SMPN 9 in Bandung City period 1 April-25 May 2018. The results of this study showed that asthmatic children with overnutrition have a 3.4 times greater restrictive ventilatory defect risk than asthmatic children with normal nutrition (OR:3.4, 95\%CI: 1.4-8.5, p=0.014). Conclusion, asthmatic children with overnutrition have more restrictive ventilatory defect effects than asthmatic children with normal nutrition.
\end{abstract}

Key words: Asthma, children, lung function, overnutrition 


\section{Pendahuluan}

Asma merupakan salah satu penyakit tidak menular kronik darisaluran pernapasan paruyang menyebabkan inflamasi dan penyempitan. Saat ini penyakit asma masih menunjukkan prevalensi yang tinggi. World Health Organizations atau WHO mengestimasikan terdapat 235 juta orang menderita asma di dunia yang umumnya terjadi pada anak dan akan terus meningkat hingga 400 juta orang pada tahun 2025, lebih dari $80 \%$ kematian akibat asma terjadi di negara berpendapatan rendah sampai menengah, serta 383.0oo kematian disebabkan oleh asma. ${ }^{1}$

Berdasar atas Kuesioner ISAAC didapatkan bahwa prevalensi asma anak di Asia pada usia 13-14 tahun sekitar 12,6\% dan mengalami peningkatan sebesar $0,39 \%$, sebanyak $26,5 \%$ terjadi di Singapura yang mengalami peningkatan 0,79\%, Filipina 20,9\% dengan peningkatan 0,47\%, Jepang 19,9\% dengan peningkatan $0,12 \%$ dan Indonesia menduduki sekitar 12,4\% dengan peningkatan prevalensi $1,80 \% .^{2}$

Jawa Barat memiliki prevalensi penderita asma pada usia 5-14 tahun sebesar 2\% pada tahun 2007 dan mengalami peningkatan $1,9 \%$ pada tahun $2013 .{ }^{3}$ Salah satu penelitian menyimpulkan asma sering berhubungan dengan gizi lebih dalam pengembangan maupun memperparah penyakit asma tersebut. ${ }^{4}$ Secara nasional masalah gemuk pada anak usia $5^{-12}$ tahun masih tinggi, yaitu 18,8\% terdiri atas 10,8\% gemuk dan $8,8 \%$ obesitas. Pada usia $13-15$ tahun prevalensi gemuk 10,8\%, terdiri atas 8,3\% gemuk dan 2,5\% obesitas. ${ }^{5}$ Jawa Barat sendiri memiliki prevalensi gizi lebih kelompok usia 6-12 tahun 8,5\% dan kelompok usia $13-15$ tahun $2,5 \%$. Bandung merupakan salah satu kota di Jawa Barat yang memiliki prevalensi gizi lebih $>10 \%$, yaitu $11,4 \% .^{6}$

Mekanisme yang berperan terhadap asma yang disertai gizi lebih adalah dengan memengaruhi fungsi saluran pernapasan. Beberapa faktor yang berperan di antaranya genetik, perkembangan, hormon, dan mekanik. Perubahan pola pernapasan pada penderita gizi lebih pada anak asma menyebabkan volume paru menurun diakibatkan oleh perubahan pada otot polos dan fungsi pernapasan, terdapat peran adipocytes of cytokines dan beberapa mediator lain seperti interleukin-6, TNF- $\alpha$, eotaksin, dan leptin. Beberapa faktor tersebut menyebabkan proses inflamasi pada saluran pernapasan. ${ }^{4}$

Penelitian ini bertujuan menganalisis efek gizi lebih terhadap fungsi paru pada anak asma.

\section{Metode}

Penelitian analitik observasional ini dilakukan dengan rancangan kasus kontrol. Sampel diambil dari 84 siswa yang memiliki riwayat asma dengan 42 siswa sebagai kasus (asma dengan gizi lebih) dan 42 siswa sebagai kontrol (asma dengan gizi normal). Data diperoleh dengan melaksanakan wawancara mempergunakan kuesioner ISAAC untuk menentukan diagnosis asma anak. Selanjutnya, dilakukan penilaian fungsi paru langsung menggunakan spirometri, serta mengukur tinggi badan memakai mikrotoa dan berat badan dengan timbangan yang hasilnya dirujuk pada grafik
Z-score WHO untuk mengukur indeks massa tubuh. Penelitian ini dilakukan di SMPN 1 dan SMPN 9 Kota Bandung periode 1 April-25 Mei 2018.

Kriteria inklusi pada penelitian ini adalah anak usia 12-15 tahun yang mempunyai riwayat asma dengan gizi lebih. Kriteria eksklusi adalah anak yang sedang mengalami serangan asma, batuk berdarah, dan mempunyai riwayat status gizi kurang/buruk. Uji statistik yang dilakukan, yaitu uji chi-square.

Penelitian ini telah disetujui oleh Komite Etik Penelitian Kesehatan Fakultas Kedokteran Universitas Islam Bandung dengan Nomor: 313/Komite Etik.FK/ III/2018.

\section{Hasil}

Hasil penelitian karakteristik demografi berdasar atas status gizi dapat dilihat pada Tabel 1.

Tabel 1 menunjukkan rerata berat badan responden pada gizi lebih sebesar $58 \mathrm{~kg}$, lebih tinggi dibanding dengan pada gizi normal. Rerata usia antara gizi lebih dan gizi normal adalah sama, demikian juga rerata tinggi badan antara status gizi lebih dan normal adalah sama. Rerata indeks massa tubuh siswa dengan gizi lebih yaitu $26 \mathrm{~kg} / \mathrm{m}^{2}$, lebih besar dibandingkan dengan gizi normal.

\section{Tabel 1 Karakteristik Demografi berdasar atas Status Gizi}

\begin{tabular}{ccc}
\hline & Status Gizi Anak dengan \\
\cline { 2 - 3 } Demografi & \multicolumn{2}{c}{ Asma } \\
\cline { 2 - 3 } & $\mathbf{n = 4 2}$ & $\mathbf{n = 4 2}$ \\
\hline Usia $(\operatorname{tahun} \pm \mathrm{SD})$ & $\mathbf{1 4} \pm \mathbf{1}$ & $\mathbf{1 4} \pm \mathbf{1}$ \\
$\mathrm{BB}(\mathrm{kg} \pm \mathrm{SD})$ & $44,5 \pm 5,9$ & $58,0 \pm 9,5$ \\
$\mathrm{~TB}(\mathrm{~cm} \pm \mathrm{SD})$ & $150,4 \pm 7,9$ & $150,6 \pm 8,0$ \\
$\mathrm{IMT}\left(\mathrm{kg} / \mathrm{m}^{2} \pm \mathrm{SD}\right)$ & $\mathbf{2 0} \pm 2$ & $26 \pm 3$ \\
\hline
\end{tabular}

Hasil penelitian rerata nilai fungsi paru (FEV1, FVC, dan FEV1/FVC) berdasar atas status gizi pada anak asma. Nilai rerata FEV1 pada status gizi lebih adalah $87 \%$ lebih kecil dibanding dengan gizi normal, yaitu $93 \%$. Nilai rerata FVC pada gizi lebih lebih kecil dibanding dengan gizi normal (Tabel 2).

Hasil penelitian rerata nilai fungsi paru (FEV1, FVC, dan FEV1/FVC) berdasar atas jenis kelamin pada anak asma dapat dilihat pada Tabel 3 yang menunjukkan bahwa nilai rerata FEV1 pada laki-laki 96\% lebih besar dibanding dengan perempuan dan untuk FVC nilai median $85 \%$ pada laki-laki.

Tabel 4 menunjukkan bahwa anak dengan fungsi paru RVD pada gizi lebih (kasus) 74\% atau sebanyak 31 anak lebih besar dibanding dengan gizi normal (kontrol) 26\% (11 responden). Nilai Odds Ratio (OR) sebesar 3,411 (pada IK95\%: 1,363-8,542) secara statistik mempunyai hubungan yang bermakna antara gizi lebih pada asma dan kejadian $\operatorname{RVD}(p=0,014)$, artinya bahwa anak asma gizi lebih mempunyai risiko RVD 3,4 kali dibanding dengan anak asma gizi normal. 
Tabel 2 Rerata Nilai Fungsi Paru berdasar atas Status Gizi

\begin{tabular}{ccc}
\hline \multirow{2}{*}{$\begin{array}{c}\text { Nilai Fungsi } \\
\text { Paru }\end{array}$} & \multicolumn{2}{c}{ Status Gizi Anak dengan Asma } \\
\cline { 2 - 3 } & Gizi Normal & Gizi Lebih \\
& $\mathbf{n}=\mathbf{4 2}$ & $\mathbf{n = 4 2}$ \\
\hline FEV1 $(\% \pm$ SD) & $93 \pm 12$ & $87 \pm 12$ \\
FVC $(\% \pm$ SD) & $84 \pm 10$ & $81 \pm 17$ \\
FEV1/FVC & $118 \pm 110-118$ & $118 \pm 106-178$ \\
$(\% \pm$ min.-maks.) & & \\
\hline
\end{tabular}

Tabel 3 Rerata Nilai Fungsi Paru berdasar atas Jenis Kelamin

\begin{tabular}{lcc}
\hline & Jenis Kelamin anak dengan \\
\cline { 2 - 3 } Nilai Fungsi Paru & \multicolumn{2}{c}{ Asma } \\
\cline { 2 - 3 } & Laki-laki & Perempuan \\
& $\mathbf{n = 3 4}$ & $\mathbf{n = 5 0}$ \\
\hline FEV1 (\% \pm SD) & $96 \pm 14$ & $86 \pm 15$ \\
FVC (\% \pm min.-maks.) & $85 \pm 62-121$ & $78 \pm 39-126$ \\
$\begin{array}{l}\text { FEV1/FVC }(\% \pm \text { min.- } \\
\text { maks.) }\end{array}$ & $118 \pm 108-118$ & $118 \pm 106-178$ \\
\hline
\end{tabular}

paru menurun yang diakibatkan oleh perubahan pada otot polos dan fungsi pernapasan, Terdapat peranan adipocytes of cytokines dan beberapa mediator lain seperti interleukin-6, TNF- $\alpha$, eotaksin, dan leptin. Beberapa faktor tersebut di atas menyebabkan proses inflamasi pada saluran pernapasan. ${ }^{4,8}$

\section{Simpulan}

Anak asma dengan gizi lebih mempunyai efek restrictive ventilatory defect lebih banyak dibanding dengan anak asma gizi normal.

\section{Ucapan Terima Kasih}

Ucapan terima kasih penulis sampaikan kepada pimpinan SMPN 1 dan SMPN 9 Kota Bandung.

\section{Daftar Pustaka}

1. World Health Organization. Asthma. 31 August 2017 [diunduh 15 November 2017]. Tersedia dari:

Tabel 4 Hubungan antara Status Gizi dan Fungsi Paru pada Anak dengan Asma

\begin{tabular}{|c|c|c|c|c|c|c|c|}
\hline \multirow[b]{2}{*}{ Fungsi Paru } & \multicolumn{4}{|c|}{ Status Gizi Anak dengan Asma } & \multirow[b]{2}{*}{ OR } & \multirow[b]{2}{*}{ IK 95\% } & \multirow[b]{2}{*}{$\mathbf{p}^{*}$} \\
\hline & $\begin{array}{r}\text { Giz } \\
n=42\end{array}$ & & $\begin{array}{r}\mathbf{G i} \\
\mathrm{n}=4\end{array}$ & bih & & & \\
\hline Normal & 23 & 55 & 11 & 26 & & & \\
\hline RVD & 19 & 45 & 31 & 74 & 3,411 & $1,363-8,542$ & 0,014 \\
\hline
\end{tabular}

* Uji chi-square

\section{Pembahasan}

Berdasar atas hasil analisis statistik didapatkan hubungan yang bermakna antara status gizi lebih dan fungsi paru pada anak asma. Mekanisme hubungan status gizi lebih terhadap penurunan fungsi paru pada anak asma dapat disebabkan oleh perubahan patologis pada bronkus (airway remodeling) yang terjadi pada saluran respiratori. Inflamasi dicetuskan oleh berbagai faktor termasuk alergen, virus, olahraga, dll. Faktor tersebut juga menimbulkan respons hiperreaktivitas pada saluran respiratori penderita asma. Inflamasi dan hiperreaktivitas menyebabkan obstruksi saluran respiratori. ${ }^{7}$

Pada penyempitan saluran respiratori yang secara berlebihan merupakan patofisiologi dan secara klinis paling relevan pada penyakit asma. Perubahan otot polos saluran respiratori (hiperplasia dan hipertrofi) yang terjadi secara sekunder menyebabkan perubahan kontraktilitas. Selain dari itu, inflamasi pada dinding saluran respiratori terutama daerah peribronkial dapat memperberat penyempitan saluran respiratori selama kontraksi otot polos.?

Terdapat beberapa faktor lain yang berperan dalam memperberat penyakit asma yang disebabkan oleh gizi lebih di antaranya genetik, perkembangan, hormon, serta mekanik. Terjadi perubahan pola pernapasan pada penderita gizi lebih yang menyebabkan volume http://www.who.int/en/news-room/fact-sheets/ detail/asthma.

2. Wong GWK, Leung TF, Ko FWS. Changing prevalence of allergic diseases in the AsiaPacific region. Allergy Asthma Immunol Res. 2013;5(5):251-7.

3. Kementerian Kesehatan Republik Indonesia. Profil kesehatan Indonesia tahun 2013. Jakarta: Kemenkes RI; 2014.

4. Boulet LP. Influence of obesity on the prevalence and clinical features of asthma. Clin Invest Med. 2008 Dec 1;31(6):E386-90.

5. Badan Penelitian dan Pengembangan Kesehatan, Kementerian Kesehatan Republik Indonesia. Riset kesehatan dasar (Riskesdas) Jakarta: Badan Litbang Kesehatan, Kemenkes RI; 2013.

6. Lestary H, Susyanty AL, Hermawan A, Yuniar Y, Sari ID, Rosita, dkk. Pokok-pokok hasil riset kesehatan dasar Provinsi Jawa Barat tahun 2013. Jakarta: Badan Litbang Kesehatan, Kemenkes RI; 2013.

7. Supriyatno B, Kartasismita CB, Setyanto DB, Yani FF, Nataprawira HMD, Setiawati L, dkk. Pedoman nasional asma anak. Edisi ke-2. Jakarta: UKK Respirologi PP IDAI. 2004.

8. Amanda G. Obesitas dan asma. CDK. 2012;39(1):36-7. 